\title{
In the Flesh? Anthropodermic Bibliopegy Verification and Its Implications
}

"In teaching bookbinding I have found that mere mention of human
skin aroused such curiosity and brought forward so many questions
often from the meekest and usually least interested."

- Rigby Graham ${ }^{1}$

Special collections hold a host of objects that lie outside the anticipated disintegrating newsprint or leather-bound tomes. Sometimes the items, at least as far as their provenance informs, appear to be rather abnormal. Within the Cassel Collection, held at Beeghly Library at Juniata College, was one such volume: Bibliotheca Politica. ${ }^{2}$ Abraham H. Cassel (1820-1908) collected widely during his lifetime, amassing a collection of 50,000 volumes. On the front flyleaf of Bibliotheca Politica, Cassel wrote: "This book [is] bound in human skin." As will be seen, this is not a unique notation, nor is it unusual for such an inscription to be the only bit of information to suggest the binding material. Subsequent peptide mass fingerprinting of samples taken from the binding of Bibliotheca Politica proved it to be made of sheepskin. While this result led to a mingled sense of disappointment and relief, it did spark the author's curiosity into this historical binding practice.

Anthropodermic bibliopegy, the process of binding books in human skin, was a secretive practice that fell out of favor in the early twentieth century. ${ }^{3}$ Initially driven by the books' owners and anatomists, many of these items have now made their way into institutional collections. As with change in ownership, so too do societal expectations change and need to be addressed. For most of these books, "many of the documented cases and extant texts where provenance is established, the remains are of European skin-origin. Typically they were the skins of prisoners, the poor, occasionally donated, or in some cases provided through...grave robbing." ${ }^{4}$ As such, these would not fall

1. Rigby Graham, "Bookbinding with Human Skin," The Private Library 6 (January 1, 1965): 14.

2. The full title is Bibliotheca Politica: or, A Discourse By Way of Dialogue, Whether Monarchy be Jure Divino: Collected Out of the Most Approved Authors, both Ancient and Modern. Dialogue the First. California State University of Northridge also has a volume of this text, but theirs had no notations or other indication to suggest that it was bound in human skin.

3. Lawrence S. Thompson, Bibliologia Comica or Humorous Aspects of the Caparisoning and Conservation of Books (Hamden, Conn.: Archon Books, 1968), 152.

4. Sandy O'Sullivan, "Human Remains: Anthropodermic Bibliopegy and the Appeal of the Extreme in Challenging the Continuing External Management of Indigenous Remains," Ngoonjook: A Journal of Australian Indigenous Issues 30 (2007): 80.

*@ 2016 by Jacob Gordon (CC BY-NC [https://creativecommons.org/licenses/by-nc/4.0/]). 
under the concerns of the Native American Grave Protection and Repatriation Act or the related Protocols for Native American Archival Materials, as they do not concern the remains of indigenous peoples. ${ }^{5}$ There instead is a class component; some of the more active practitioners of anthropodermic bibliopegy were educated white doctors, often involved in the anatomist trade. This market was supplied with bodies that were disproportionally drawn from the marginalized people, especially black or povertystricken populations. ${ }^{6}$ While the fact that human skin was used in such a fashion is contemporarily problematic, particularly in a post-Holocaust era, these books can serve as a focal point in discussing how special collections can balance modern ethics with their more traditional role of preservation. In more direct terms, it is a debate between respectful treatment of human remains and the role of research repositories. What follows is an exploration of attempts to verify anthropodermic volumes and the different ways their holding institutions dealt with their results. ${ }^{7}$

Before addressing these volumes, it is useful to look at how the flesh was prepared, for "it is the method of preservation that has the greatest effect on the subsequent deterioration of the skin." In "Bookbinding with Human Skin," Rigby Graham detailed the process skin underwent to become leather:

...skin, human or otherwise, can, if treated with lime and scraped, become parchment or, if tanned, become leather.... In the case of leather depending on the tanning, the human skin thickens and becomes soft and pliable. It is saturated in a strong solution of alum, Roman vitriol and common salt, dried then dressed.... It can of course be stained or dyed almost any colour and would in the normal state of things, and to the untutored eye be indistinguishable from pig or goat. ${ }^{9}$

Human skin leather is highly durable, having the added advantage of being more water-resistant than other leathers. ${ }^{10}$ Visually, these books are like any

5. "Native American Graves Protection and Repatriation Act," in United States, National Center for Cultural Resources (U.S.), and National Conference of State Historic Preservation Officers, Federal Historic Preservation Laws: The Official Compilation of U.S. Cultural Heritage Statutes (Washington, D.C.: Cultural Resources, National Park Service, U.S. Dept. of the Interior, 2006), 167-83; First Archivists Circle, Protocols for Native American Archival Materials, 2007, available online at http:/ / www2.nau.edu/libnap-p/ protocols.html [accessed 10 August 2016].

6. Edward C. Halperin, "The Poor, the Black, and the Marginalized as the Source of Cadavers in United States Anatomical Education,” Clinical Anatomy 20, no. 5 (July 1, 2007): 493.

7. The author was concerned primarily with items held in United States collections, with a digression to Australia. Not explored here are several books in the United Kingdom that are the results of anatomists preserving the skin of condemned criminals to bind their trial accounts or other books.

8. C.V. Horie, "Deterioration of Skin in Museum Collections," Polymer Degradation and Stability 29, no. 1 (1990): 114.

9. Graham, "Bookbinding with Human Skin," 14-15 (bold text added by author).

10. Jason Schwartz, "Classic Texts-In the Flesh," The Daily Pennsylvanian, January 18, 2016, available online at www.thedp.com/article/2006/01/classic_texts_in_the_flesh\#comment8900 [accessed 12 August 2016]. 
other leather-bound item; indeed, if one did not know the leather's source, it would be easy to overlook. When these books had an inscription to suggest a human skin binding, they could become items considered worth placing in special collections, as having an unusual binding, or a further criterion for the decision, as noted by Carolyn Harris in "Selection for Preservation": "Any item that may need to be authenticated in the future must be retained in original format for further study." 11

In learning that these books are bound in human skin, should that skin be considered as an individual, an object, or as art? Perhaps it is a combination of those three categories, or something else entirely? ${ }^{12}$ Ethically, here is the major issue: if these books are human remains, what happens next, particularly in the cases of those that are unconfirmed? Looking at modern medical guidelines for conducting research on cadavers, an emphasis is placed on the "need to balance the potential benefits from this research with moral obligations to the recently dead... cadavers should be treated in a manner that is consistent with respect for the value and dignity of the once-living person." 13 The Consensus Panel on Research with the Recently Dead states that there is "direct continuity between the body of a person who has died and the living person," so the deceased's life goals and wishes should be respected. Honoring these wishes expresses respect and prevents distress of those still living and communicates that their own posthumous wishes will be obeyed. Friends and families are likely to have a strong association with the body and their memories of their loved one; disrespectful treatment can cause intense feelings of guilt and anguish. ${ }^{14}$ In most of the cases described here, there is not information to link the skin with the individual who was its source. Testing can confirm that the binding material is human, but it cannot provide enough detail to offer individual identification. Below are summaries of those institutions with an anthropodermic volume in their collection that pursued at least some form of verification.

\section{Visual Inspection}

Prior to the twentieth century, the only method of verification was by visual means, often with mechanical magnification. Book owners or collectors could either trust the provenance of a book or submit it to visual inspection, often by

11. Carolyn Harris, "Selection for Preservation," in Preservation Issues and Planning, eds. Paul Banks and Roberta Pilette (Chicago: American Library Association, 2000), 213.

12. Sanchita Balachandran, "Among the Dead and Their Possessions: A Conservator's Role in the Death, Life, and Afterlife of Human Remains and Their Associated Objects," Journal of the American Institute for Conservation 48, no. 3 (2009): 200.

13. Rebecca D. Pentz et al., "Ethics Guidelines for Research with the Recently Dead," Nature Medicine 11, no. 11, (2005): 1145-49.

14. Ibid. 
forensic experts. ${ }^{15}$ The Chronicles of Nawat Wuzeer Hyderabed (1848) has belonged to the Newberry Library of Chicago since 1919, part of John M. Wing's bequest. According to its inscription, the book was "Found in the Palace of the King of Delhi, September 28th, 1857, seven days after the assault. James Wise MD Bound in Human skin." On the back flyleaf, Wise also explained the content, written in Arabic script, as "a narrative of events connected with Dekkan comprising biographies, deeds, genealogies, etc. of the sundry notables." An unnamed anatomist from Chicago examined the book and verified the manuscript as being bound in human skin based on pore structure. ${ }^{16}$ Following the publication of Audrey Niffenegger's novel The Time Traveller's Wife in 2003, the Newberry Library set up a page to address frequently asked questions, as a character in the novel works at the Newberry and the human skin book is mentioned. The book has a call number but did not have a card in the main catalog, effectively and quietly hiding it from the wider public. Librarians took The Chronicles to the Newberry's conservation lab, where it was observed under a microscope and compared with animal leathers. Conservation staff are of the opinion that the binding is goatskin. ${ }^{17}$ In this case, the book serves as an item that draws attention to the institution, particularly with its inclusion in a best-selling novel.

A book of poetry bound in human skin, Poems on Various Subjects, Religious and Moral (1773) by Phillis Wheatley, is in the University of Cincinnati Library's Rare Books Collection. Donated during the 1950s by Burt Smith, this volume was printed for A. Bell, Bookseller, and sold by Messrs. Cox and Berry of Boston. ${ }^{18}$ The book was taken to the University's Tanner Research Laboratory in Winton Terrace for examination. Based on the hair follicle patterns, researchers determined the spine and corners to be bound in human skin, with the rest being sheepskin. Historically, the library had been circumspect about the book, but this attitude has been chang-

15. The Library of Congress's human skin book Scrutinium Scripturarum was sent to the Federal Bureau of Investigation for confirmation, who found it to be bovine. As noted in Carolyn Marvin, "The Body of the Text: Literacy's Corporeal Constant," Quarterly Journal of Speech 80, no. 2 (1994): 134.

16. Daniel K. Smith, "Bound in Human Skin: A Survey of Examples of Anthropodermic Bibliopegy," in The Morbid Anatomy Anthology, eds. Joanna Ebenstein and Colin Dickey (Brooklyn: Morbid Anatomy Press, 2014), 380; Maryrose Cuskelly, Original Skin: Exploring the Marvels of the Human Hide (Berkeley: Counterpoint, 2011), 165; Thompson, Bibliologia Comica, 146; Lawrence S. Thompson, "Tanned Human Skin," Bulletin of the Medical Library Association 34, no. 2 (1946): 97; Walter Hart Blumenthal, Bookmen's Bedlam: An Olio of Literary Oddities, (Freeport, New York: Books For Libraries Press, 1955), 79.

17. “Time Traveler's Wife," The Newberry, available online at https://www.newberry.org/time-traveler-s-wife [accessed 27 July 2016].

18. Kevin Grace, "Poetry Month and ARB-Phillis Wheatley’s Poetry," UC Libraries, available online at http:/ / libapps.libraries.uc.edu/liblog/2014/04/ poetry-month-and-arb-phillis-wheatleys-poetry/ [accessed 14 April 2014]; "Poems on Various Subjects, Religious and Moral," Summon, available online at http://uc.summon.serialssolutions.com/document/show?id=FETCHMERGED-uc_catalog_ b182169732\&s.cmd=removeFacetValueFilter\%28ContentType $\% 29 \&$ s.fvf $=$ ContentType $\% 2 \mathrm{CBook}+\%$ $2 \mathrm{~F}+\mathrm{eBook} \% 2 \mathrm{Cf} \&$ s.light $=\mathrm{t} \& \mathrm{~s} . \mathrm{q}=\% 22 \mathrm{Poems}+\mathrm{on}+$ Various + Subjects $\% 2 \mathrm{C}+$ Religious + and + Moral $\% 22$ [accessed 3 May 2016]. Burt Smith owned two other copies, one of which was donated to the Cincinnati Public Library and is also bound in human skin. Also mentioned in Blumenthal, Bookman's Bedlam, 78. 
ing. Initial worries revolved around the recognition of assumptions made that the African American author's skin was used to bind the book, which was not the case. The book is featured annually at the start of the Rare Books Library monthly lecture series, "50 Minutes One Book," where academics and researchers discuss rare books in the archives. ${ }^{19}$ The University of Cincinnati's book benefits its institution by serving as an entry point in discussing the rare books in the collection, and it is reassuring to see the staff have discussed the possible implications. While there has not been conclusive testing, the uncertainty can help to draw in visitors.

In the collection of the National Library of Australia is The Poetical Works of Rogers, Campbell, J. Montgomery, Lamb, and Kirke White: Complete in One Volume (1829). Former owner Edward Petherick had penciled on one of the front pages the inscription, "Bound in Human skin." Prior to 1890, bookbinder C. Egleton, of Fleet Street rebound the book. A small sticker bearing his name is found on the inside cover. The book was added to the National Library of Australia's collection in 1911 as part of a donation from Petherick of 16,500 books. ${ }^{20}$ The catalogue listing also indicated "Confirmed; see file 430/01/0226." According to Sue Chan, reference librarian at the National Library of Australia, this file contains a 1992 report from two pathologists from the John Curtin School of Medical Research. These pathologists used a stereomicroscope to examine the binding and took a number of samples to do connective tissue tests. They concluded with 99 percent certainty that the binding was of human origin. Their decision was based in part on the amateurish nature of the tanning that suggested suspicious methods of obtaining the skin. As the library is satisfied with this verification, they do not plan to submit samples for further testing. ${ }^{21}$ Here again, a human skin book serves as a boon to publicity, having been featured in news articles as recently as $2011 .^{22}$

\section{DNA Testing}

Institutions and collectors of anthropodermic books may be wary of trying to authenticate their bindings. If nothing else, it could affect their value or, as already explored, can bring publicity related to the individual item. As previously noted, prior to the modern era, the process of identification and confirmation of human origin was by visual examination; but, beginning in the twentieth century, more scientific

19. Ben Goldschmidt, "Rare Books Library Home to Skin-Bound Book," News Record, October 23, 2013, available online at www.newsrecord.org/for_the_record/rare-books-library-home-to-skin-boundbook/article_5591898a-3be4-11e3-a399-001a4bcf6878.html [accessed 12 November 2015]. Goldschmidt states that Burt Smith's third copy went to Rutgers University, but there is no evidence of it within their catalog.

20. Cuskelly, Original Skin, 168-72.

21. Sue Chan, e-mail reply to author, May 17, 2015.

22. "Poems Bound Up in a Human Skin," Canberra Times, August 7, 2011, available online at www. canberratimes.com.au/act-news/poems-bound-up-in-a-human-skin-20110807-1wv7c.html [accessed 31 March 2014]. 
analysis became possible. One example of the challenges with authentication even today is that of journalist Mark Jacobson's lampshade. Jacobson wanted to know for certain if a lampshade in his possession, found in New Orleans after Hurricane Katrina, was one of the infamous human skin lampshades produced by the Nazis. Initially, Jacobson hoped to determine if it was of human origin and then further if it was from a person of Jewish descent.

As part of his verification process, Jacobson brought the lampshade to the Bode Technology Group of Lorton, Virginia, who had helped with DNA identification of victims from the 9/11 terrorist attacks. They took a sample, cleaned it to offset any contamination of handling, and tested the DNA for a fee of $\$ 5,000$. Their 2007 findings seemed to confirm that the lampshade was indeed of human origin. ${ }^{23}$ In the 2012 documentary, Human Lampshade: A Holocaust Mystery, the Mason Lab in New York City retested the lampshade. This time it was confirmed as 100 percent of bovine origin. The earlier false positive was determined to be either due to a contaminated sample or the imprecision of earlier technology. ${ }^{24}$ Finding an uncontaminated portion of heavily handled items such as a book or lampshade can be a challenge.

Another example of improving technology is evident in a study published in the Philosophical Transactions B, in which researchers successfully analyzed the genomes of historical livestock from parchment samples. ${ }^{25}$ A 2001 study, "The Survival of PCR-amplifiable DNA in Cow Leather," investigated 14 historic book bindings from the Göttingen State University Library alongside other parchment and hide samples. Researchers found "parchment generally offers good chances of retaining ancient DNA, leather contains endogenous DNA only in sporadic cases. A large amount of tannins and high temperature at a site can lead to a total loss of endogenous DNA," ${ }^{26}$ which suggests that the DNA analysis of book leathers is not a possibility, as the tanning process that materials undergo to become leather usually destroys the DNA. The sensitivity of the testing can also lead to false positives due to human handling, as seen in Jacobson's case.

23. Mark Jacobson, The Lampshade: A Holocaust Detective Story from Buchenwald to New Orleans (New York: Simon \& Schuster, 2010), 70-71, 340-42.

24. Steven Hoggard, Human Lampshade: A Holocaust Mystery (documentary, 2012). Though the Appendix to Jacobson's book includes the complete report from Bode Technology who recommend: "that reference samples be obtained from any individuals that have handled the lampshade... to determine if they can or cannot be excluded as contributors to the DNA profile obtained from the lampshade." Jacobson, The Lampshade, 340.

25. M.D. Teasdale et al., "Paging through History: Parchment as a Reservoir of Ancient DNA for Next Generation Sequencing," Philosophical Transactions of the Royal Society of London B: Biological Sciences 370, no. 1660 (Jan. 19, 2015).

26. J. Burger, I. Pfeiffer, S. Hummel, R. Fuchs, B. Brenig, and B. Herrmann, "Mitochondrial and Nuclear DNA from (Pre)Historic Hide-Derived Material," Ancient Biomolecules 3, no. 3 (Mar. 2001): 227, 235 . 


\section{Peptide Mass Fingerprinting}

For those seeking to confirm the animal of origin from a sample, peptide mass fingerprinting (PMF) offers accurate and comparatively inexpensive results. Whereas Jacobson had Bode Technology focus on DNA from his samples, PMFs rely on collagen, which is "a highly insoluble structural protein... that is particularly resistant to decay." ${ }^{27}$ Not only is it long lasting, but "collagen-based material (skin, intestine, esophagus and tendon) is used pervasively in a wide variety of applications" such as toys, clothing, tools, models, religious items, or books. ${ }^{28}$ Another point in their favor is that PMFs are significantly less expensive, costing approximately $\$ 100$ per sample. A PMF is created from miniscule object samples that undergo a protein digestion procedure, followed by mass spectrometric analyses. Samples of anthropodermic bibliopegy would undergo the following process:

Enzymatic digestion is used to cleave collagen at specific amino acid sites forming a mixture of peptides. The amino acid sequence of each protein is unique, thus the resultant mixture of peptides is unique. The peptide mixture is analyzed by MALDI [matrix assisted laser desorption ionization mass spectrometry] resulting in a mass spectrum of characteristic marker peptides or a "peptide mass fingerprint." Small evolutionary variations in collagen's amino acid sequence result in species-specific markers...which... allow us to distinguish human parchment or tanned leather from other mammalian sources. ${ }^{29}$

The following cases will demonstrate the success of employing this method, in terms of both confirming and disproving examples, and the institutions' treatment of the volumes in light of identification.

\section{Harvard University}

First published in 2006, a Harvard Crimson article "The Skinny on Harvard's Rare Book Collection," was reintroduced to the Internet in March 2014 after running in the Daily News. ${ }^{30}$ The Crimson article detailed three books held within the Harvard libraries that were purported to be bound in human skin. Unbeknownst to the

27. M. Buckley and M.J. Collins, "Collagen Survival and Its Use For Species Identification in Holocene-lower Pleistocene bone fragments from British Archaeological and Paleontological Sites," Antiqua 1, no. e1), 2011: 1 .

28. D. Kirby, M. Buckley, E. Promise, S. Trauger, and T.R. Holdcraft, "Identification of CollagenBased Materials in Cultural Heritage," Analyst 138, no. 17 (2013): 4849.

29. Daniel Kirby, Anna N. Dhody, Beth Lander, and Richard Hark, "You Can't Tell a Book by Its Cover: Analytical Adventures in Anthropodermic Bibliopegy," Abstract, SciX Conference 2015: Mass Spectrometry in Forensics, September 29, 2015, available online at https: / /www.scixconference.org/ program / archive?p=7224\&yearSelect $=2015$ [accessed 26 April 2016].

30. "Margaret Eby, "Harvard Libraries Contain Three Books Bound in Human Skin," Daily News (New York), March 26, 2014, available online at www.nydailynews.com/blogs/pageviews/ harvard-libraries-books-bound-human-skin-blog-entry-1.1735535 [accessed 10 August 2016]. 
author of the Daily News article, Harvard Libraries had begun testing of their bindings in the spring of 2014 and would begin to publicize their results.

In April 2014, the Harvard Law School Library's blog Et Seq. posted results for Practicarum quaestionum circa leges regias Hispanice primce partis nouce collectionis regice (1605-1606). This book has an inscription, on page 794: "The bynding of this booke is all that remains of my dear friend Jonas Wright, who was flayed alive by the Wavuma on the Fourth day of August 1632. King Mbesa did give me the book, it being one of poore Jonas chiefe possessions, together with ample of his skin to bynd it. Requiescat in pace." ${ }^{31}$ Harvard acquired the book in February 1946 from a New Orleans dealer at a cost of $\$ 42.60 .{ }^{32}$ At the request of HLS Library curators and Weissman Preservation Center staff, Dr. Daniel Kirby, at the time a conservation scientist at the Harvard University Art Museums' Straus Center, employed PMF to analyze nine samples taken from the front and back covers, binding, and glue. The glue was identified as a mixture of cattle and pig collagen, with the binding conclusively established as sheepskin. ${ }^{33}$ This book had been previously tested in 1992 with inconclusive results. ${ }^{34}$ The testing of this volume is notable for two reasons: first, the series of tests Harvard had undertaken brought a wave of publicity to this topic. Second, it was the first use of PMF to confirm a book's binding as nonhuman. It also began the trend of expressing this news with attempts at humor; the web address for the June 2014 blog post containing "caveat lecter." ${ }^{35}$

In 1989, the Countway Library, located on the campus of the Harvard Medical School, acquired a French translation of Ovid's Olympe, ou Metamorphoses (1597) that was bound in human skin, adding it to the Boston Medical Library collection. Jack Eckert, the institution's reference librarian, was doubtful of its authenticity. "I think even this is somewhat doubtful as [the book] doesn't greatly resemble others I've seen in the past." ${ }^{36}$ PMF testing confirmed that it was bound in sheepskin. ${ }^{37}$ This was the second book mentioned in the Crimson article, and the second attribu-

31. As quoted in Karen Beck, " 852 RARE: Old Books, New Technologies, and 'The Human Skin Book' at HLS,” Et Seq, April 3, 2014, available online at http: / / etseq.law.harvard.edu/ 2014/ 04/852-rareold-books-new-technologies-and-the-human-skin-book-at-hls / [accessed 7 April 2014].

32. Smith, "Bound in Human Skin," 382; Oliver Robinson, "Bound for Glory: The Macabre Practice of Book Bindings Made of Human Skin,” Rare Book Review 33 (2006): 30; Blumenthal, Bookmen's Bedlam, 80.

33. Beck, "852 RARE: Old Books, New Technologies, and 'The Human Skin Book' at HLS."

34. Samuel P. Jacobs, "The Skinny on Harvard's Rare Book Collection," The Harvard Crimson, last modified February 2, 2006, available online at www.thecrimson.com/article/2006/2/2/the-skinny-onharvards-rare-book [accessed 31 March 2014].

35. "The Science of Anthropodermic Binding," Houghton Library Blog, last modified June 4, 2014, available online at http:/ / blogs.law.harvard.edu/houghton/2014/06/04/caveat-lecter/ [accessed 20 May 2015]. An unfortunate trend, that was also reflected in "852 RARE: Old Books, New Technologies, and 'The Human Skin Book' at HLS." That begins: "Baaaaaad news for fans of...."

36. Jacobs, "The Skinny on Harvard's Rare Book Collection."

37. Kate Womersley, “'To Dust You Shall Return:' Books Bound in Human Skin,” Remedianetwork, June 6, 2014, available online at https: / / remedianetwork.net/2014/06/06/to-dust-you-shall-returnbooks-bound-in-human-skin/ [accessed 14 May 2015]. 
tion that was challenged and proved false, but the results of the PMF testing were not reported directly. Instead, the results were mentioned as an aside in an article about the book featured in the next paragraph. ${ }^{38}$

Des Destinées de l'ame (1877) by Arsène Houssay became part of the Harvard Library collection in 1954. In the late 1880s, Houssay gave the book to Dr. Ludovic Bouland, who decided to have the gift bound in the skin of an unclaimed female patient who died of apoplexy in a French mental hospital. Bouland had the skin tanned and commemorated by inscribing in the cover:

This book is bound in human skin parchment on which no ornament has been stamped to preserve its elegance. By looking carefully you easily distinguish the pores of the skin. A book about the human soul deserved to have a human covering: I had kept this piece of human skin taken from the back of a woman. It is interesting to see the different aspects that change this skin according to the method of preparation to which it is subjected. ${ }^{39}$

The next known owner was John B. Stetson, Jr., who loaned the book to the university in 1934, his widow offering it as a gift in 1954. Its binding was tested using several different methods. Senior Rare Book Conservator Alan Puglia is 99 percent certain the binding is of human origin. Dr. Kirby, while noting that the PMF was consistent with a human source, states that other closely related primates cannot be eliminated "because of the lack of necessary references." 40

While it is the first confirmation by PMF, this copy of Des Destinées de l'ame raises more troubling issues. Unlike the prior anthropodermic books mentioned so far, in this item we have a provenance. The skin came from a deceased, unnamed female patient. Paul Needham, a Rare Books \& Special Collections Librarian for Princeton, wrote a recommendation that in part stated: "although preservation is a central responsibility of libraries and museums, it is not one isolated from wider questions of ethics." Needham further suggested that the purpose of the binding matters; in this case "there is no trace of a research purpose that could benefit

\footnotetext{
38. The Science of Anthropodermic Binding," Houghton Library Blog, last modified June 4, 2014, available online at http:/ / blogs.law.harvard.edu/houghton/2014/06/04/ caveat-lecter/ [accessed 20 May 2015]. The relevant text: "Similar testing done on books thought to be bound in human skin at the Harvard Law School Library and the Harvard Medical School's Countway Library revealed that they both were actually bound in sheepskin."

39. "Bound in Human Skin," Houghton Library Blog, May 24, 2013, available online at http:/ /blogs. harvard.edu/houghton/2013/05/24/bound-in-human-skin/ [accessed 8 April 2014]. Translated from French.

40. "The Science of Anthropodermic Binding," Houghton Library Blog; Blumenthal, Bookmen's Bedlam, 80.
} 
humanity," and the flesh binding should be removed and given a respectful burial. ${ }^{41}$ Todd Samuelson briefly worked at the Houghton Library and recalled a librarian telling him "That a typical practical joke of some earlier generations at the Houghton Library was to ask newly hired student employees to fetch the book; only when they returned, book in hand, would they be told the source of its covering in a kind of backhand hazing." ${ }^{42}$ This attitude certainly does not show respectful treatment of the dead, or any sort of research interest. This item is the first book confirmed to most likely have an anthropodermic binding by PMF. The findings at Harvard suggests, unsurprisingly, that the number of works allegedly bound in human skin is likely to be much larger than those actually bound in this fashion.

\section{University of Notre Dame}

Hesburgh Libraries of the University of Notre Dame owns a book allegedly bound in human skin that also claimed Christopher Columbus as a former owner. Opera Joannis Pici Mirandule Comitis Concordie (1504) by Giovanni Pico della Mirandola was presented to Columbus by Cardinal Ximenes and donated to the Columbia Library at the Cathedral of Seville, before its transportation to Peru. At least, this is what the donor, Sebastian Carroll Braganza de la Coralla, who acquired it as "a trophy of war," claimed. Braganza donated it to the University of Notre Dame in $1916 .{ }^{43}$ In 1999, conservator Liz Dube and a colleague who had done leather research magnified the cover to find a follicle pattern but could not rule out human as a possible source. Further testing was considered but not pursued at that time. ${ }^{44}$

Following the New York Times reporting on Harvard's testing in January 2015, a sample was taken from under the pastedown and sent to the New York Medical Examiner's Office. ${ }^{45}$ Next, the conservators used a Nikon AZ100 Macroscope to take high-quality images of the binding, from which they "observed some very interesting patterns, but nothing conclusive as yet." Definitive results were not expected by this method, but it was attempted due to ease of access. They planned to take those images and compare them with other closeup images of leathers. ${ }^{46}$

41. Paul Needham, "A Binding of Human Skin in the Houghton Library: A Recommendation," June 25, 2014, available online at www.princeton.edu/ needham/Bouland.pdf [accessed 10 August 2016].

42. Todd Samuelson, "Still Life," Printing History, NS 16 (July 2014): 42-43. Samuelson also wrote a poem about this book (Todd Samuelson, "Cast Study," in Prairie Schooner 76, no. 2 (2002): 131-32).

43. "Opera Joannis Pici Mirandule Comitis Concordie-Hesburgh Libraries, University of Notre Dame," One Search, available online at http:/ / onesearch.library.nd.edu/NDU:ndu_aleph000943748 [accessed 3 May 2016].

44. John Nagy, “The Truth Uncovered," Notre Dame Magazine, Spring 2016, available online at http:// magazine.nd.edu/news/65313/ [accessed 25 April 2016].

45. "ND Preservation-The Ball Is Rolling on Our 'Is It Human Skin?”’ January 22, 2015, available online at http:/ / ndpreservation.tumblr.com/post/108842030761/the-ball-is-rolling-on-our-is-it-humanskin [accessed 5 January 2016].

46. "ND Preservation-To the Macroscope, Batman! With the Help of Bill," February 17, 2015, available online at http:/ / ndpreservation.tumblr.com/post/111279559226/to-the-macroscope-batman-withthe-help-of-bill [accessed 5 January 2016]. 
Donald Siegel, principal scientist at the Office of the Chief Medical Examiner, used a mass spectrometry technique that provided ambiguous results. A further test of two circular punches, one from Opera, the second from a control book printed and bound in Switzerland in 1569, showed the samples to be "consistent with multiple species," but with pig peptides as the most common. By October 2015, Siegel was asked to forward the samples to Daniel Kirby, who used PMF and shared his findings of a pigskin binding in December. Not only did these analyses lead to the refutation of the binding, but provenance research, begun well before the testing, revealed donor Braganza's colorful life. ${ }^{47}$ As should be apparent by now, the notation of bound in human skin or an amazing tale of past ownership or skin source should not be seen as proof. In fact, this tale alongside the item being a war trophy should raise more doubts than confirmation.

\section{Brown University}

The John Hay Library has four anthropodermic texts, confirmed by PMF in April 2015, which is second only to Philadelphia's Historical Medical Library of the College of Physicians. Avid book collector and Brown alumnus William Easton Louttit, Jr. owned three of them, all of which, alongside a book owned by another alumnus, were given to the library in the $1960 \mathrm{~s}^{48}$ The first of these books is De Humani Corporis Fabrica Libri Septem.: Cum Indice Rerum \& Uerborum Memorabilium Locupletissimo (1568), a text on human dissection. At some point during the 1860s, Josse-CorneilleEugène Schavye bound two copies of Fabrica in human skin. One copy found its way to North America following its sale in 1874, where William Louttit, Jr. became the owner. The second copy remained in Europe, eventually becoming part of the Belgian royal family's library during the reign of King Albert I until disappearing in the 1990s. ${ }^{49}$ In April 2015, the Brown volume was confirmed by PMF to be of human origin "or that of a closely related primate," ${ }^{50}$ which makes it the second medical book confirmed as being bound in human skin. The book's content focused on the act of dissection, which was often the direct antecedent of anthropodermic bibliopegy. Perhaps Schavye, like Bouland, felt a text about humanity deserved a human binding?

The second of Louttit's books, an English translation of Adolphe Belot's Mademoiselle Giraud, ma femme (1891) is a book that ties closely to the fictional world

\footnotetext{
47. Nagy, "The Truth Uncovered."

48. Thompson, Bibliologica Comica, 147; Taryn Martinez, "In a Literal Bind: Hay has books bound with anthropodermic leather," The Brown Daily Herald, January 31 2006, available online at www.browndailyherald.com/2006/01/31/in-a-literal-bind/ [accessed 16 August 2016].

49. Omer Steeno and Maurits Bisebrouck, "Stolen and Lost Copies of Vesaliu's' Farbrica." Acta Medico-Historica Adriatica 10, no. 2 (2012): 228-29. This source refutes Daniel Smith's ("Books Bound in Human Skin," 389) claim that King Leopold II of Belgium owned the book, but Smith himself notes that the books in his study were selected more for their story than veracity (Ibid., 393).

50. "Andreae Vesalii Bruxellensis, Inuictissimi Caroli V. Imp. Medici, De Humani Corporis Fabrica Libri Septem. : Cum Indice Rerum \& Uerborum Memorabilium Locupletissimo-Brown University Library Search," Josiah, available online at https://search.library.brown.edu/catalog/b2010003 [accessed 3 May 2016].
} 
of H.P. Lovecraft. Belot's novel recounts the disintegration of a marriage following a husband's discovery of his wife's homosexuality and his subsequent mental breakdown. Handwritten on the volume's front flyleaf is "Bound in human skin / S.B.L.," believed to be former head of Brentano's book department, S.B. Luyster. ${ }^{51}$ The library also has a letter written by Sam Loveman of Bodley Book Shop to Louttit, further attesting to the binding's authenticity, dated November 10, 1936. In it, Loveman states, "[W]e are assured by our consignee that this book is of unquestioned authenticity so far as the human skin binding is concerned." Loveman was a friend of Lovecraft's, and it is believed that their visit to a Brooklyn graveyard was the inspiration for Lovecraft's short story, "The Hound." PMF testing in April 2015 confirmed the binding material as "the skin of a human being or that of a closely related primate." ${ }^{52}$ This example gives unfortunate credence to the more dubious claims of erotic works bound in skin from a woman's breast, but it also shows at least two people familiar with rare books affirming the binding. ${ }^{53}$

The other two books at Brown are two different editions of Hans Holbein's Dance of Death, both rebound for private collectors. The earlier version was printed in 1816. In 1893, British bookbinder Joseph Zaehnsdorf wrote to the book dealer L.W. Bangs, Esq.:

Dear Sir, The copy of 'Dance of Death' which I sold you a short time since was covered in human skin. Unfortunately as the book was rather large, and the material covering rather scanty, I was obliged to split the leather in two: the result of this is that the skin which is quite smooth is on one side [front cover], and the rough unfinished skin on the other [spine back cover]. The material which covers this book is from exactly the same piece of skin. Yours Obediently, Zaehnsdorf. ${ }^{54}$

The aforementioned William Louttit also owned the 1898 edition of the Dance of Death. It was bound in human skin by the Chicago bookbinder Alfred Cox prior to its 1903 exhibition at the Grolier Club by its then-owner Harry Selfridge. ${ }^{55}$

\footnotetext{
51. Thompson, Bibliologica Comica, 147.

52. Smith, "Books Bound in Human Skin," 392-93;"Mademoiselle Giraud, My Wife-Brown University Library Search," Josiah, available online at https:// search.library.brown.edu/catalog/b3339531 [accessed 3 May 2016].

53. Thompson, Tanned Human Skin, 98; Blumenthal, Bookmen's Bedlam, 90; Thompson: "The publisher of obscene books, Isidore Liseux, claimed to have seen the one volume in octavo edition (1793) of Justine et Juliette by the Marquis de Sade Bound in female breasts." Blumenthal quotes the above sentence directly. 54. "The Dance of Death; / from the original designs of Hans Holbein—Brown University Library Search," Josiah, available online at http:/ / josiah.brown.edu/record=b2668712 S5 [accessed 16 August 2016]. 55. "The Dance of Death by Hans Holbein, with an introductory note by Austin Dobson- Brown University Library Search,'Josiah, available online at http://josiah.brown.edu/record=b1715688 S5 [accessed 16 August 2016].
} 
Sam Streit, then Library Director, described these four books as "more idiosyncrasies

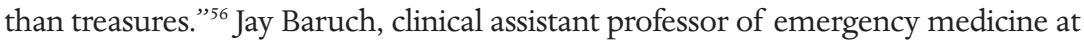
Brown and director of the Ocean State Ethics Network, voiced "the notion that the body is sacred. Does using body parts in such a way somewhat cheapen our conception of the body?" Baruch also mentioned concerns related to informed consent and the possibility of using the fact of the binding as "an occasion for inquiry." Streit agreed that there are ethical issues with owning these books, while also noting they were created at a different time, but determining identities could be costly and damaging and that "The tanning process destroys much of the DNA." 57 Dr. Lindsey Fitzharris, a medical historian, shares the opinion on consent, stressing "that concepts of consent don't really start to evolve until the 20th century. We can't really judge the past when these things were happening." 58 On the John Hay Library's "Frequently Asked Questions" page, the library notes "These books are only made available for scholarly research in order to protect their bindings." ${ }^{59}$ This decision has the advantages of discouraging the merely curious and limiting the number of people physically handling the books. However, they are still put out on display; one of the Dance of Death volumes was featured in a Special Collections Senior Open House in $2013 .^{60}$

\section{Historical Medical Library of the College of Physicians of Philadelphia}

The Historical Medical Library of the College of Physicians of Philadelphia houses the largest number of confirmed anthropodermic volumes in the country. In March 2015, Dr. Richard Hark, the H. George Foster Chair of Chemistry at Juniata College, took minute samples of five book bindings. Dr. Kirby, now a conservation scientist in private practice, confirmed the samples as human via PMF. ${ }^{61}$ Of those five books, Dr. John Stockton Hough bound three. From 1868 to 1874, Dr. Hough worked as a resident physician and in his own medical practice in Philadelphia. ${ }^{62}$

56. Taryn Martinez, "In a Literal Bind: Hay Has Books Bound with Anthropodermic Leather," The Brown Daily Herald, January 31 2006, available online at www.browndailyherald.com/2006/01/31/in-aliteral-bind/ [accessed 16 August 2016].

57. Ibid.

58. Simon Davis, "Let's Talk about Binding Books with Human Skin: An Interview with Dr. Lindsey Fitzharris," VICE, January 13, 2015, available online at www.vice.com/read/binding-books-with-humanskin-135 [accessed 13 March 2015].

59. "Frequently Asked Questions: 8. Is it true the John Hay Library has books bound in human skin?" Brown University: John Hay Library, available online at http:/ / library.brown.edu/hay/faq.php\#7 [accessed 15 August 2016].

60. Jennifer Betts, "Special Collections Senior Open House, May 22, 3 pm-5 pm," Brown University Special Collections, December 9, 2014, available online at http://blogs.brown.edu/bulspecialcollections / [accessed 16 August 2016].

61. Beth Lander, "Welcome to This Inaugural Edition of Fugitive Leaves," Fugitive Leaves: A Blog from the Historical Medical Library of the College of Physicians of Philadelphia, October 1, 2015, available online at www.collegeofphysicians.org/histmed/welcome/ [accessed 3 May 2016]. The other two books are An Elementary Treatise on Human Anatomy (1863) written and bound by Joseph Leidy and De conceptione adversaria: disce, homo, de tenui constructus pulvere, quae te edidt in lucem conditione Deus (1686) by Charles Delincourt.

62. F.B. Rogers and T.A. Horrocks, "Dr. John Stockton Hough: Medical Bibliophile and Bibliographer," Transactions \& Studies of the College of Physicians of Philadelphia 11, no. 4 (Dec. 1989): 355-61. 
While a resident physician at Philadelphia General Hospital, Dr. Hough carried out the autopsy for Mary Lynch, who died at age 28 of a combination of tuberculosis and parasitic worms on January 16,1869 . She was buried in a pauper's grave. ${ }^{63}$ While carrying out the autopsy, Dr. Hough removed a piece of skin from Mary's thigh and surreptitiously preserved and tanned it using a chamber pot in the hospital's basement. This skin would not be used as binding materials until Dr. Hough became a gentleman farmer in West Trenton, New Jersey. Mary Lynch's skin was used to bind Louis Barles's Les Nouvelles decouvertes sur Toutes les Parties Principales de L'homme, et de la femme (1680), Louise Bourgeois's Recueil des Secrets; Auquel Sont Contenues Ses Plus Rare Experiences Pour Diverses Maladies, Principalement des Femmes, Avec Leurs Embelissement (1601), and Robert Couper's Speculations on the Mode and Appearances of Impregnation in the Human Female (1789). In each of these books, Dr. Hough recorded an inscription about "Mary L," leaving her last name unwritten.

For De Concepitone Adversaria; Disce, Homo, de Tenui Constructus Pulvere, Quae te Edidit in Lucem Conditions Deus by Charles Drelincourt (1686), Dr. Hough used the tattooed wrist of another patient who had died in the Philadelphia hospital in 1869. He did not bind any of these books until 1887. Dr. Hough also bound a twovolume set of the 1857-1889 Catalogue des Sciences Médicales by the Bibliothèque Nationale. Although the source of this last piece of skin is not noted, it was tanned in June 1887 and used to bind the two books in January of $1888 .{ }^{64}$

In 1901, the College of Physicians of Philadelphia purchased Dr. Hough's entire collection, consisting of 3,247 volumes and 2,070 pamphlets. The staff of the college library separated out the duplicate and nonmedical materials that were later sold to the University of Pennsylvania. ${ }^{65}$ Again, we have a physician making use of the dermis of a patient. What makes this case unique in this study is we have the full name of the skin source. Dr. Hough made cursory attempts to protect, or possibly hide, Mary's name by choosing to only use her last initial. After her death in 1869 , Dr. Hough tanned the skin and in 1887 bound three books with it, all of which bear an inscription explaining what he had done. As in the case of Des Destinées de L'âme, we have the skin of a disadvantaged woman put to reuse, but the research carried out into her background does not reveal any offspring. While some unclaimed bodies might have been lacking familial relations or anyone else

63. Beth Lander, "The Skin She Lived In: Anthropodermic Books in the Historical Medical Library," Fugitive Leaves: A Blog from the Historical Medical Library of the College of Physicians of Philadelphia, October 1, 2015, available online at www.collegeofphysicians.org/histmed/skin-she-lived-in/ [accessed 26 May 2015].

64. Laura Ann Guelle, "Anthropodermic Book-Bindings," Transactions \& Studies of the College of Physicians of Philadelphia 26 (Dec. 2002): 85-89; mentioned briefly in Paul McPharlin, "Curious Book Bindings," Notes and Queries 153 (July 2, 1927): 7; also mentioned in Thompson, Tanned Human Skin, 97; Todd Samuelson, "Still Life," 46-47; Blumenthal, Bookmen's Bedlam, 81.

65. Rogers and Horrocks. "Dr. John Stockton Hough,” 359. 
to speak for them, others might have been left in this manner due to their relations' inability to afford a funeral. ${ }^{66}$

\section{University of Memphis}

In possession of the McWherter Library at the University of Memphis is L'Idolatrie Hvgvenote Figurée au patron de la vieille payenne (1608) by Louis Richeome. According to the MARC display for this volume, the book is bound in human skin. Orientation guides mention the book to incoming freshmen on a library tour, often receiving astonished gasps. ${ }^{67}$ Previously belonging to Barry Brooks, of the family for whom the Memphis Brooks Museum of Art was named, the book was acquired by the library on October 29, 1986, from Burke’s Book Store in Midtown for $\$ 500$. According to oral tradition, Brooks had acquired it while traveling in France in the early 1950s. Ed Frank, curator of special collections, has said that, as of 2011, the university has paid for at least three lab tests to determine if it is actually bound in human skin; but, at the time of writing, those results have not been disclosed to the public. It does not seem likely that the university will, as the book is not available to view publicly; one must make an appointment. This approach is intended to encourage curious students to learn to use the library and see what is has to offer. ${ }^{68}$

\section{Slippery Rock University}

The 1972 publication of El Largo Viaje by Tere Medina-Navascués, held at the Bailey Library at Slippery Rock University in Pennsylvania, was believed to have an anthropodermic binding. This book of Spanish erotic poetry was said to have been bound in the preserved torso skin from a member of the Aguadilla tribe of the Mayaguez Plateau region in Puerto Rico. ${ }^{69}$ Initially purchased for the regular collection in the 1970s, the condition and note in the front were not discovered until a shifting project years later. The volume was then moved to Special Collections for preservation. ${ }^{70}$ The library's catalogue page for this book, however, has been updated to include this annotation: "An analytical report done by the Harvard/ Straus Art Museums in 2014 determined that this book is not covered with human skin but with very convincing faux leather." ${ }^{71}$

66. Thomas W. Laqueur, The Work of the Dead: A Cultural History of Mortal Remains (Princeton, N.J.: Princeton University Press, 2015), 360-61.

67. "Lidolatrie [i.e. Idolotrie] Hvgvenote Figurée Au Patron de La Viellile Payenne. Diuissée En Huit Hures \& Dediée Au Roy Très Chrestien de France \& de Navarre Henri IIII. Par Levys Richeome," Encore, last modified May 3, 2016, available online at http:/ / catalogquicksearch.memphis.edu/iii/encore/ record/C_Rb1446125 [accessed 13 May 2015].

68. Michelle Corbet, "Library’s Special Collections Home to a Skin-Crawling Read," The Daily Helmsman, October 28, 2011, available online at www.dailyhelmsman.com/archives/library-s-special-collectionshome-to-a-skin-crawling-read/article_32aa0769-8ad3-52e0-9fcf-169c5246e227.html [accessed 8 April 2014].

69. "University Archives Houses Vast Treasure Chest," The Rock Magazine, Fall 2012, 35, available online at http://issuu.com/www.sru.edu/docs/fall2012-rock-magazine/ 35 [accessed 18 May 2015].

70. Judith Silva, e-mail reply to author, May 2, 2016.

71. "Staff View: El Largo Viaje," Keystone Library Network, available online at https:/ /vufind.klnpa. org/vufind/Record/rock.33610/Details\#tabnav [accessed 3 May 2016]. 


\section{Conclusion}

Anthropodermic bibliopegy, for the most part, has ceased to be actively practiced. ${ }^{72}$ Instead, it has now become both a source of publicity and debate about ethics and preservation. When volumes bound in human skin are identified as part of library collections, they are often viewed as morbid or sensational items, more famous for their unusual bindings than their content. As technology advances and peptide mass fingerprinting is used more widely, some of these volumes are having their macabre pedigrees stripped, while others are being confirmed.

Ultimately, questions raised are as varied as the bindings on books. While the Society of American Archivists Ethics and Association of College and Research Librarians Code of Ethics for Special Collections Librarians have no provisions for dealing with human remains, ${ }^{73}$ the existence of the Protocols for Native American Archival Materials formed in April 2006, sixteen years after the enactment of the Native American Graves Protection and Repatriation Act, shows a willingness of the field to establish best practices for handling culturally sensitive materials. ${ }^{74}$ The anthropodermic volumes should be treated sensitively, even when unconfirmed. They should not be objects of ghoulish entertainment; instead, they should be respected as an individual's bodily remains, objects of respectful study, with an awareness of their binding alongside discussion of their content. They may aid in campus discourse on rare books, but they should not be used merely to titillate and encourage library use. Items not authenticated should still be stored in special collections, ideally separately from other materials. Considering the low cost of PMF, there should be few impediments to verification, for, if nothing else, the testing and refutations have shown that, if a story seems too extraordinary to be true, it probably is.

72. Dard Hunter's autobiography notes a young widow hiring the shop in which he was working to bind a memorial book in the skin of her deceased husband. Dard Hunter, My Life with Paper (New York: Knopf, 1958), 41-42. As recently as 1994, Donal Russell of Springfield, Oregon, willed his flesh to be skinned and tanned to bind a copy of his poetry. His widow went to court to challenge the mortuary's resistance due to state laws against corpse abuse. The request was denied. "Man's last wish is to have body skinned, hide tanned; widow asks judge to approve his request," Buffalo News (New York), February 13, 1994.

73. Society of American Archivists "Code of Ethics for Archivists," SAA Core Values Statement and Code of Ethics, (revised 2012), available online at http:/ / www2.archivists.org/statements/saa-corevalues-statement-and-code-of-ethics\#code_of_ethics [accessed 10 August 2016]; also, the Association of College and Research Librarians, "Code of Ethics for Special Collections Librarians," RBMS - Rare Books \& Manuscripts Section, October 2003, available online at http://rbms.info/standards/code_of_ethics/ [accessed 10 August 2016].

74. "Native American Graves Protection and Repatriation Act," in United States, National Center for Cultural Resources (U.S.), and National Conference of State Historic Preservation Officers, Federal Historic Preservation Laws: The Official Compilation of U.S. Cultural Heritage Statutes (Washington, D.C.: Cultural Resources, National Park Service, U.S. Dept. of the Interior, 2006), 167-83; First Archivists Circle, Protocols for Native American Archival Materials, 2007, available online at http: / www2.nau.edu/ libnap-p/protocols.html [accessed 10 August 2016]. 